\title{
US agencies split over inquiry into effects of radiation experiments
}

Washington. Deep divisions have emerged between the US Department of Health and Human Services and the Department of Energy over the value of an investigation into human radiation experiments in the United States that has been launched by the Clinton administration.

The \$3-million-a-year investigation will address public concern that has been heightened by Hazel O'Leary, the secretary of energy. She has been campaigning since December to "open up" the history of her department's predecessor, the Atomic Energy Commission (AEC) (see Nature 367, 303; 1994).

But Donna Shalala, the secretary of health, is known to be worried that the government-wide investigation will waste her officials' time, while fuelling public paranoia about all use of radiation in research and medicine.

The investigation is expected to yield

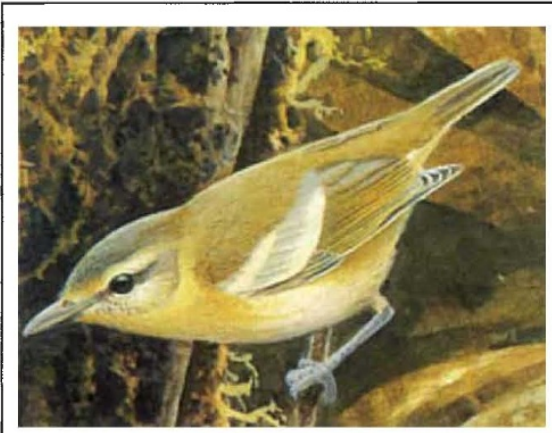

London. Money can't buy you a title they say, but it could buy you the honour of naming this rare bird. The charity BirdLife International is seeking donations towards preserving this new species of vireo, a small insectivorous bird discovered in the rainforest of the Colombian Andes in 1991.

Its discoverer, Paul Salman, from the University of East Anglia, has waived his traditional right to have the bird named after him and it will now be named after the company or individual donating the most to its conservation. The as-yet nameless bird comes from the Choco region on the western slopes of the Andes and is thought to be unique to that region, where it has now been found at two separate sites.

Some 30,000 hectares of forest have been bought as a reserve in an area otherwise earmarked for development, and around $\mathbf{£ 7 0 , 0 0 0}$ (US\$105,000) is needed towards establishing an endowment fund in conjunction with a Colombian foundation to run the reserve and ensure its survival. valuable lessons about scientific ethics, according to its chairwoman, Ruth Faden of Johns Hopkins University in Baltimore. But critics are concerned that the enquiry, set up by the president, manned by eminent lawyers and scientists, and supported by a strong full-time staff, will merely result in more public confusion and mistrust on the radiation testing issue.

At the first meeting of Faden's panel last week, the problems facing the investigation - such as the vast amount of data to be considered, and the ill-defined boundaries of the task - led some members to doubt whether it could be completed in a year as planned.

The investigation is to deal with all radiation experiments carried out on humans between 1946 and 1974, when the health department issued new guidelines to safeguard human subjects.

Shalala told the meeting that the Department of Health and Human Services, which provides $\$ 11$ billion for biomedical research annually through the National Institutes of Health (NIH), could provide a billion sheets of paper on radiation experiments if asked.

She also reminded the meeting that threequarters of all NIH projects make use of radiation in some way. Like other government agencies, NIH awaits guidance from the new panel on exactly which radiation experiments it wants to know about.

Speaking at an informal lunch of Congress's Biomedical Research Caucus last Friday, the day after the inquiry was launched, Harold Varmus, the director of $\mathrm{NIH}$, voiced his concern publicly. One aspect of his job that he did not like, he said, was devoting effort "at a time of scarce resources, to digging through a billion sheets of paper in the Clinical Centre about experiments we did in 1950".

In common with other government agen- cies, NIH tried to avoid involvement in O'Leary's campaign when it started in December. Health department officials sought to draw a line between its health-related research and the then-AEC's interest in the effects of radiation from atomic bombs.

But as public interest rose, President Bill Clinton aligned himself with O'Leary and instructed all agencies to cooperate.

Faden says that the investigation will concentrate on three tasks, three duties and three themes. Its first task, she says, will be to establish what standards should be applied to radiation experiments during that period. Second, the investigation will review the experiments against that standard, and consider the need for follow-up studies, official apologies and financial compensation. Third, it will look at current experimental practices and policies.

The investigation's duties, Faden says, are to satisfy three constituencies: government that it can be trusted; the public that it can trust; and scientists that they will be treated fairly. The three themes that will run through the investigation, according to Faden, will be the ethics of research, the role of secrecy in a democracy, and the competing rights of the citizen and the state.

Welcoming the investigation, Senator John Glenn (Democrat, Ohio), chairman of the Senate's Governmental Affairs Committee, said it was likely that its report would lead to legislation to enable compensation of victims of radiation experiments. He added that the panel should run for more than a year if it felt this was necessary.

The panel will digest existing data on radiation testing, take evidence from the public and produce an interim report in six months that will include an estimated time of arrival for its final report.

Colin Macilwain

\section{'Neglect at an end' for Irish science}

Munich. The prospects for science in the Republic of Ireland took a turn for the better last week when the government announced that it is planning to resume funding for a strategic research programme which it abandoned last year.

This year, the government will make available I£1 million (US\$1.42 million) for research grants in eight technological areas, including biotechnology, advanced manufacturing technology and advanced materials. In addition, it is making available I£850,000 in basic resarch grants.

Scientists have cautiously welcomed the move as a possible signal of a change in attitude towards science, whose fortunes sank to an all-time low last year when the government made available only I£150,000 in non-medical grant money. Ireland has one of the lowest investments in research in Europe, and no real science policy. But a year-long campaign by university scientists has made research funding a hot political issue (see Nature 367, 586; 1994).

The prime minister, Albert Reynolds, admitted last week that the government had been slow to recognize the importance of science and technology. But he said that this "relative neglect" is now coming to an end.

Alison Abbott 